DOI https://doi.org/10.32841/2409-1154.2019.42.2.12

\author{
Danylchenko I. V., \\ Candidate of Philological Sciences, \\ Associate Professor of Germanic Philology and Foreign Languages \\ Instruction Methods Department \\ Nizhyn Mykola Gogol State University,
}

\author{
Zotikova Yu. V., \\ Master Student of Faculty of Foreign Languages \\ Nizhyn Mykola Gogol State University
}

\title{
ADVERTISING FUNCTION OF HEADLINES IN ENGLISH INTERNET NEWS: A COGNITIVE LINGUISTIC PERSPECTIVE
}

Summary. The article studies the linguistic means of English Internet news headlines performing advertising function. Viewing headline as a riveting short-cut to the contents of an article, advertising function lies in attracting attention to the full-text. It is found that cognitively news headlines are based on the same perceptual abilities as advertising slogans captured by image-schemas - recurring dynamic patterns of human perceptual interaction and motor programs structuring our experiences. The analysis of $30 \mathrm{BBC}$ news stories and 20 advertising slogans has demonstrated that most frequently news headlines and slogans rely on force image schemas. COUNTERFORCE representing the meeting of two equally important forces that collide relies on different verbs and syntactic structures in news headlines and advertising slogans. In headlines it is denoted by the verbs to attack, to hit, to warn, and slogans draw on the verb to hit. COMPULSION denoting the source which makes the target do something relies on the verbs to force, to make, to provoke in news headlines and to make and to obey in slogans. BLOCKAGE representing a force vector encountering a barrier and then taking any number of possible directions is denoted in headlines by the verbs to reject, to jail, to sue, to trap, to poison and in slogans by the verbs to cool in the meaning to trap and to jail. RESTRAINT REMOVAL is represented by the verbs to answer, to find, to free in headlines and the verbs to let and to answer in slogans. ENABLEMENT representing a force which helps the target to exist is denoted by the verbs to create, to give, to help, to make, to vote in headlines and to give, to help in slogans. DISABLEMENT represents the force which destroys the target of the action in headlines by the verbs to kill, to lose, to reject, and slogans draw on the verbs to kill, to melt.

Key words: advertising function, headline, slogan, news discourse, linguistic means, image-schema.

Introduction. News is a piece of information represented by mass media about recent events in the country or worldwide or in a particular area of activity [5, p. 13]. This definition brings into the focus the novelty of events or situations described in the articles. But along with its informative function, news stories play an essential role in shaping the viewpoints and general ideas of the readership, or as Roberts puts it, "We know what is happening in a foreign country without traveling there, and develop a particular opinion about a public figure - a politician, a celebrity, an activist etc. - without actually meeting them" [13, p. 24].
The element of novelty is a basic building block of a news story. Every news story contains the answer to six questions: Who? What? When? Where? Why? How? [3, p. 42]. Answers to them may be represented by photos, videos, audios or by textual elements of online news stories [16, p. 43]. Since headline is the first thing the reader perceives when opening an article, the headlines' ability of attracting attention to the full-text seems prima facie and central enough to compare news headlines and advertising slogans in terms of their perception and effect on the readers. It presupposes that there are some similar functions between headlines and slogans.

The analysis of recent publications. Headlines of news texts are extensively studied in journalism and linguistics. Both of these scholarly approaches view headlines as riveting short-cuts to the contents of the articles $[4 ; 14]$. In other words, headlines basically perform two main functions: summarize the content and attract attention to the full-text article [9, p. 699]. In this paper, we refer to the latter function as to advertising. Fundamental though it may seem to be, summarizing function of headlines has been questioned by showing that they do not accurately represent the articles they introduce [1, p. 711;2, p. 26]. It has been shown that they neither improve readers' comprehension [11, p. 87], nor reveal substantial info $[15$, p. 59]. In the above cases, it was concluded that headlines make a loose, inadequate or misleading substitute for full-text news reports in a number of ways: by directing the reader's attention to an aspect of the story, by highlighting the topic in a non-objective, yet intriguing way, by oversimplifying the fulltext content, while consistently masking other relevant information. Precisely because headlines underrepresent, or over-represent, and hence misrepresent, news stories, readers' previous knowledge and sophisticated reading strategies are claimed to be critical in retrieving the explicit or implicit meaning conveyed [11, p. 101-102; 1, p. 715]. If headlines lack in informative value with respect to the article introduced, their function to attract attention, i.e. advertising function, may be more promising as a goal to fulfill and account for. Since advertising function is seen not only in slogans of different companies and products, but also in headlines of online news articles, current research is relevant and important.

The aim of this work is to study the linguistic means of English Internet news headlines performing advertising function. The material of the investigation is presented by $30 \mathrm{BBC}$ news stories 
available at http://www.bbc.com and 20 advertising slogans taken from the websites Pinterest (http://www.pinterest.com) and Trademarks411 (http://www.trademarks 411.com).

Investigation. Since the first days of our life, we gradually develop our visual focusing abilities. We learn to direct attention toward areas within the visual field and to highlight figure against a background. Authors of Internet news articles and slogans use the peculiarities of human perception to make people read the article or buy the products advertised in slogans [7, p. 62]. For this reason, we take into account the cognitive linguistic background of creating headlines and slogans using the perceptual theory of image schemas for the analysis.

The theory of image schemas suggested by Lakoff and Johnson is perception-based. According to Johnson, an image schema is a recurring dynamic pattern of our perceptual interaction and motor programs that gives coherence and structure to our experience [10]. Currently, following Potapenko (2016), four groups of images schemas are distinguished: bodily, perceptual, moto-spatial, and dynamic subdivided into motion and force schemas [12, p. 14]. Our analysis has demonstrated that most frequently news headlines and slogans are based on dynamic image schemas. The salience of dynamic relations in headlines and slogans results from their place in the kinetic and force hierarchies. The kinetic schemas position a moving object relative to a number of coordinates. The salience of the source and target of force is captured by force schemas discussed in this paper.

FORCE image schemas denote cognitive representations of our naïve understanding of physical force and various forcedynamic events in the world [6]. Journalists and marketers have been struggling to apply force relations in the process of creating news headlines and slogans through counterforce, compulsion, blockage, restraint removal, enablement and disablement verbs. The general amount of identified verbs is 24 , ten of them coincide in headlines and slogans, the other 14 differ.

COUNTERFORCE representing the meeting of two equally important forces that collide [10] relies on different verbs and syntactic structures in news headlines and advertising slogans. In news headlines COUNTERFORCE is denoted by the verbs to attack, to hit, to warn, and slogans draw on the verb to hit. The verb to meet in both headlines and slogans denotes contact. As we can notice, the similar verbs are to hit in the meaning to attack and to meet.

In the $\mathrm{BBC}$ news, verbs that denote counterforce are used in three headlines structured as simple sentences. There are three possible variants of counterforce: the full one (the source, the vector and the target), the one without the source and the one with the target omitted. The counterforce is expressed by verb 'to hit' in the headline Volcano tsunami' hits Indonesia (bbc.com/ news/23.12.2018) which has the structure of a simple sentence. Tsunami serves as the source of counterforce; the target is denoted by the object Indonesia, while the vector is represented by the predicate hits.

COUNTERFORCE without naming the source is represented in the headline Northern Ireland churches attacked almost 450 times in three years (bbc.com/news/21.08.2019). The predicate attacked refers to the vector and the object churches indicates the target. The result of the source's activity is denoted in the headline Food industry warns Gove on Brexit 'crisis. (bbc.com/news/ 11.02.2019). The subject food industry denotes a source of counterforce; the predicate warns refers to the vector while the noun crisis expresses the result.
We can observe not counterforce, but contact expressed by the verb to meet in the headline Panorama: Stacev Meets the IS Brides (bbc.com/news/ 05.08.2019). The source of contact is represented by the name of the journalist Stacey (Dooley) while the vector is denoted by the predicate meets counters the object brides. This headline differs from the previous ones by the capitalization.

In slogans, counterforce is referred to twice by verbs to hit and to meet in the structure of simple and complex sentences. The slogan having the structure of a simple sentence Have you met your life today? (Metropolitan Life) (tripwiremagazine, e-ref) represents contact by the verb to meet. In this example, the predicate meet is used in the Present Simple Tense denoting contact, the pronoun you refers to the source and the noun life names the target. Besides, in the news headline with the verb 'to meet' mentioned earlier the predicate meets refers also to the target: Panorama: Stacey Meets the IS Brides (bbc.com/news/ 05.08.2019). The contact verb is used in the slogan.

Unlike the previous slogan, the following one is represented by a complex sentence, and doesn't refer to the video and underlines the result. The slogan Power to hit pain where it hurts (Solpadeine) (YouTube, e-ref) expresses counterforce in the following way. The noun power that implies Solpadeine pills shown in the video, in the main clause denotes its source, the predicate to hit in the form of infinitive refers to the vector and counters the object pain which refers to the target. In the subordinate clause the predicate hurts emphasizes a fight between the source and the target. If we compare this slogan with the headline with the same verb to hit (Volcano tsunami hits Indonesia) we see that the slogan has got a more complicated structure, as it refers to the video.

So, counterforce in headlines is most frequently expressed by the verbs: to attack, to hit, to warn, in slogans by the verb to hit. The contact in headlines and slogans is denoted by the verb to meet.

COMPULSION denoting the source which makes the target do something [12, p. 14] relies on various verbs and syntactic structures in news headlines and advertising slogans. In news headlines, COMPULSION is denoted by the verbs to force, to make, to provoke, and the verbs to make and to obey are characteristic for slogans. The verb to make as a part of Complex Object is specific for both headlines and slogans. In the BBC news, verbs that denote compulsion are observed in three headlines with the structure of simple sentences, two of them contain Complex Object.

The compulsion is expressed by verb 'to provoke' in the headline US sanctions provoke Chinese anger (bbc.com/news/21.09.2018) which has the structure of a simple sentence. The subject sanctions denotes the source of compulsion. The source performs an action, introduced by the vector - provoke; the target is denoted by the China, while the result is represented by the object anger.

There are two cases where compulsion is represented be Complex Object with the verbs to force and to make. In the headline Focus: Cyber-attack forces company to use pen and paper (bbc. com/news/25.06.2019), the source is expressed by the subject cyber-attack which influences the target company by the vector forces to use. The infinitive to use specifies the result denoted by pen and paper.

The similar case we can observe in the headline Millie Bobby Brown: Bullies made me move school (bbc.com/news/22.05.2019). The source is represented by the subject bullies, the vector of compulsion is expressed by the Complex Object of the verb made with the help of the infinitive move without particle to. As 
in the previous example Complex Object underlines the result expressed by the object school.

In slogans compulsion is referred to two times by the verb to obey and Complex object of the verb to make in the structure of simple sentences in the Imperative Mood. In the slogan Obey your thirst (Sprite) (pinterest, e-ref), compulsion is expressed by means of vector represented by the predicate obey. The Imperative Mood shows that the source is represented by the advertisement itself. The target of compulsion is denoted by the customer which isn't mentioned in the slogan.

We can observe compulsion expressed by Complex Object of the verb to make in the slogan Make it happen (Maybelline) (dribble.com, e-ref). The source isn't mentioned, but the Imperative Mood shows that a customer himself should be the source and perform an action. The vector of compulsion is expressed by means the predicate make happen and is connected with the target represented by the object it (the aim in your life). The characteristic feature of compulsion in slogans is the omission of the source and target in the slogans, but we can understand what the advertisement means with the help of the Imperative Mood.

Thus, compulsion in headlines is most frequently represented by the verbs to force, to make, to provoke, Complex Object of the verbs to force, to make. In advertising slogans, it is expressed by the verb to obey and Complex Object of the verb to make.

BLOCKAGE representing a force vector encountering a barrier and then taking any number of possible directions $[10, p .67]$ in headlines is denoted by the verbs to reject, to jail, to sue, to trap, to poison and the verbs to cool in the meaning to trap and to jail are characteristic for slogans. As we see the similar verbs for both headlines and slogans are to jail and to trap (to cool).

In the BBC news verbs that denote compulsion are observed in five headlines with the structure of simple and compound sentences. In simple sentences adverbial modifiers of cause, place and time help to represent blockage. There are cases where all the elements of blockage are present and when the source of action is omitted.

The blockage is represented by the verb to reject in the headline Macron rejects nationalism on Armistice Dav (bbc.com/news/ 12.11.2018) in the structure of a simple sentence. The subject Macron is the source, as it performs an action. The vector of blockage is denoted by the predicate rejects, while the target is expressed by the object nationalism. We can observe the image-schema of blockage, according to which a force vector encounters a barrier represented by Macron's rejection and by means of Adverbial Modifier of time on Armistice Day.

The similar structure of blockage is observed in the headline Google to be sued by Belgium for not blurring military sites (bbc. com/news/28.09.2018). The source is denoted by the subject Google, while the vector of action is expressed by the predicate in the Passive voice to be sued. The reason for blockage is expressed by means of Adverbial Modifier of cause for not blurring military sites.

Blockage is expressed by the verb to jail and the Adverbial Modifiers of time and cause in the headline The Indian journalist jailed for a year for Facebook posts. (bbc.com/news/ 22.12.2018). The source is omitted, the subject journalist denotes the target and the predicate jailed expresses the vector. The Adverbial Modifiers of time for a year and of cause for Facebook posts explain the details and the reason of blockage to make the headline more understandable and attractive for the reader.
The next case of blockage without a source is Woman trapped in billionaire's New York lift all weekend (bbc.com/news/29.01.2019). The vector of blockage is represented by the predicate trapped which blocks the target woman. The Adverbial modifier of place in billionaire's New York lift and time all weekend, specify the vector of blockage and show the details of action to the reader.

Blockage is expressed by the verb to poison in the structure of compound sentence Salisbury Novichok attack poisoned second officer. Met confirms (bbc.com/news/ 15.08.2019). The source of blockage is expressed by the subject attack, that performs an action denoted by the vector poisoned. The target of blockage in this headline is represented by the object officer.

In slogans compulsion is referred to two times by the verbs to cool and Complex object of the verb to jail in the structure of simple sentences in the Imperative Mood. Blockage is denoted by the verb to cool in the slogan Cool the fever (Bufferin) (pinterest, e-ref). The source is omitted, but by means of the Imperative mood we can understand that the advertisement itself is a source. The vector is expressed by the predicate cool and the target is represented by the object fever.

Blockage is expressed by the verb to jail in the structure of question Got jail? Get bail (LLC GotJail?) (trademarks, e-ref) . As in the previous slogan, the source here is omitted, but from the form of question we can understand that the source is the advertisement as it asks the customer. The vector of blockage is denoted by the predicate get jailed, while the target is represented by the customers.

RESTRAINT REMOVAL in BBC headlines is denoted by the verbs to answer, to find, to free and the verbs to let in the meaning to free and to answer are met in slogans. As we see the similar verbs for both headlines and slogans are to answer and to free (to let).

In the $\mathrm{BBC}$ news verbs that denote restraint removal are observed in three headlines with the structure of simple sentence. There are cases where all the elements of blockage are present and when the source of action or the target is omitted.

The canonical organization of restraint removal is encoded by the verb to answer in the news headline Sir Billy Connolly answers questions from his fellow comedians (bbc.com/news/21.10.2019) which has the structure of a simple sentence. Sir Billy Connolly denotes the restraint removal source, the target is named by the object questions, while the vector is represented by the predicate answers. The same structure occurs in the headline Thailand frees refugee footballer (bbc.com/news/ 11.02.2019) where the restraint removal is denoted by the verb to free, expressed by the predicate. As in the previous headline, the source of action is represented by a proper name Thailand. The target of restraint removal is denoted by the object footballer.

The omission of the restraint removal source is observed in the headline Needles found in New Zealand strawberries (bbc.com/ news 25.09 .2018 ). The vector is expressed by the predicate found, while the target is denoted by the subject needles. The adverbial modifier of place in New Zealand strawberries specifies the target and makes the article more attractive to the reader.

In slogans restraint removal is referred to two times by the verbs to answer and to let in the structure of simple sentences. There are two variants of restraint removal structure: 1) with the missing source; 2) with the missing target.

The verb to let evokes the structure of restraint removal with the missing source in the slogan Let your fingers 
(Yellow Pages) (pinterest, e-ref). Though the source is not mentioned here, we can understand from the Imperative Mood, that a customer (you) is the source. The vector is represented by the predicate let $d o$, while the object fingers expresses the target of restraint removal. Moreover, another object, the walking, denotes the result of action

The verb to answer evokes the structure with the missing target in the headline We answer to the higher authority (Hebrew National) (pinterest, e-ref). The source of restraint removal is represented by the subject we that means the produce of Hebrew National. The vector of action is expressed by the predicate answer in the Present Simple Tense, and both the target and the result of action are omitted.

To conclude, the verbs to answer and to free (to let) trigger restraint removal in both $\mathrm{BBC}$ headlines and slogans. The usage of the Present Simple Tense is similar for headlines and slogans, only one headline Needles found in New Zealand strawberries contains Participle II. The omission of the target or the source is characteristic for restraint removal in both slogans and headlines that makes them memorable.

ENABLEMENT representing a force which helps the target to exist [8, p. 67] in headlines is denoted by the verbs to create, to give, to help, to make, to vote and slogans draw on the verbs to give, to help. As we can see, the similar verbs are to give and to help.

In the BBC news verbs that denote ENABLEMENT are used in five headlines with the structure of simple and complex sentences. The canonical organization of enablement is encoded by verb 'to vote' in the headline Macedonians vote over renaming country (bbc.com/news/ 30.10.2018) which has the structure of a simple sentence. Macedonians denotes the enablement source, the target is named by the object group renaming country while the vector is represented by the predicate vote.

The headline having the structure of a complex sentence The cities that make living easy (bbc.com/news/ 10.09.2018) represents enablement in the following way. The noun cities in the main clause denotes its source, the predicate make in the subordinate clause refers to the vector while the noun living refers to the target.

Metonymically represented source of enablement is designated by the name of a country which is the case with the headline How France created the metric system (bbc.com/news/24.09.2018). Its subject France denotes the people of a country, the vector denoted by the predicate create represents a past action, while the result of enablement is coded by the object group metric system.

Instead of target some headlines denote the result of a source's activity which is the case with the previous headline and the next one: Japan emperor gives_emotional farewell (bbc.com/news/ 23.12.2018). The subject emperor denotes a source of enablement, the predicate gives refers to the vector while the noun farewell names the result.

The verb to help denotes enablement in the headline Volunteers help to maintain South Yorkshire police cars (bbc.com/ news/ 18.05.2019). The source of enablement is represented by the subject - volunteers. It influences the target -cars by means of vector, denoted by the predicate help. The infinitive to maintain is used to emphasize the target. In this example the author uses the Present Simple Tense of the verb. In four examples predicates are used in the Present Simple Tense and the only one (created) in the Past Simple Tense.

Slogans trigger enablement two times by means of verbs to give and to help. We have analyzed slogans with images and without them. In slogans verbs of enablement emphasize the result of using the product.

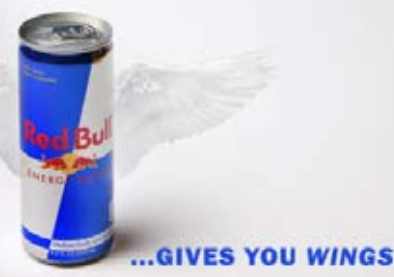

Slogans interact with pictures which makes their structure different from that of headlines as the following example suggests: It $[$ Red Bull] gives you wings (The Guardian, e-ref). In this slogan that source of enablement is represented by the Red Bull drink which is shown in the picture preceding the slogan. The target is denoted by the pronoun you, which refers to the consumer while the vector is named by the verb give. The picture explains that the noun wings metaphorically denotes the result represented by vital energy. If we compare this slogan with the headline with the same verb 'to give' (Japan emperor gives emotional farewell) we see that the slogan has got a more complicated structure, as the source is denoted in the picture. Besides, the source and the result are presented by the picture and the object wings in the advertisement.

In the cited example $\underline{A \text { Mars }}$ a day helps you work, rest and play (The Guardian, e-ref) the predicate help in the Present Simple Tense denotes enablement, the noun Mars refers to the source represented by a chocolate, the pronoun you names the target while the infinities work, rest and play indicate the result. It this slogan the usage of infinitives may be explained by the stylistic device of repetition. Unlike the previous slogan, the following one doesn't refer to the picture and the enablement verb to help emphasizes the result with the help of three infinitives. However, in the news headline with the verb 'to help' discussed earlier the infinitive to maintain refers to the target: Volunteers help to maintain South Yorkshire police cars (bbc.com/news/ 18.05.2019). Slogans which contain pictures produce more influence on customers.

To conclude, enablement in headlines is most frequently expressed by the verbs to create, to give, to help, to make, to vote and in slogans - by means of verbs to give, to help. Unlike the Internet news headlines slogans have a more complicated structure with the verbs of enablement emphasizing the result in order to convince customers to buy advertised products. The source and the result in slogans can be presented with the help of the picture, it means that advertising slogans belong to multimodal texts. In news headlines enablement verbs specify the target, refer to the result.

DISABLEMENT is opposite to ENABLEMENT and represents the force which destroys the target of the action [10] in headlines is denoted by the verbs to kill, to lose, to reject, and slogans draw on the verbs to kill, to melt. As we can see, the similar verb is to kill.

In the $\mathrm{BBC}$ news verbs that denote DISABLEMENT are used in three headlines with the structure of simple sentences and standard structure of disablement image schema (with all the elements present, such as a source, a vector and a target). Two headlines are related to the present and one to the past. 
The verb to kill evokes disablement in the headline Raging Californian fires kill 25 (bbc.com/news/ 11.11.2018). The source of action is represented by the subject fires, while the vector is denoted by the predicate kill in the Present Simple Tense that specifies the target 25 which names the amount of people.

The verb to reject represents disablement in the headline China's Huawei rejects US criminal charges (bbc.com/news/ $29.01 .2019)$. The source of action is expressed by the subject, denoted by the Proper name Huawei. The source disables the target represented by the object criminal charges through the vector rejects in the Present Simple Tense.

The verb to lose triggers disablement in the context of past events in the headline I lost my whole life to infected blood scandal (bbc.com/news/ 24.09.2018). The source is represented by the pronoun $I$ that is foregrounded and denotes the subject. The vector is represented by the predicate lost in the Past Simple Tense to emphasize the result denoted by the object life.

In the advertising slogans verbs that denote DISABLEMENT are used in two of them with the structure of simple sentences. Unlike headlines, slogans contain pictures, which help to understand advertisements and to attract customers.

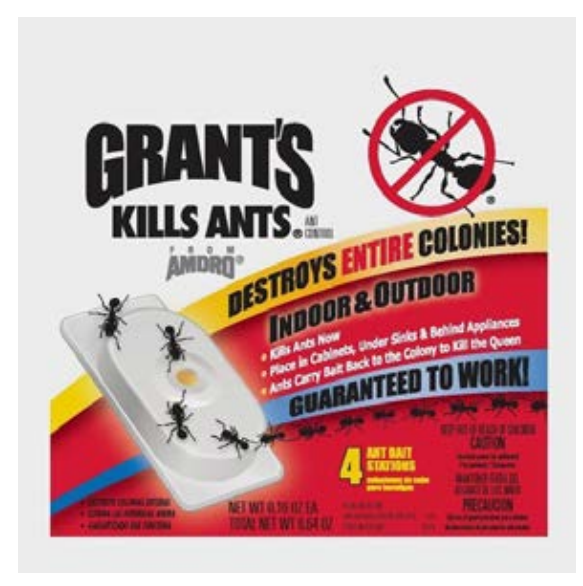

The canonical structure of disablement is denoted by the verb to kill in the advertising slogan Grant's kills ants (Grant's) (pinterest, e-ref). The source is represented by the name of produce. The vector is denoted by the predicate kills in the Present Simple Tense while the target is expressed by the object ants. Besides, the slogan contains a picture to visualize principles of action and to show the result.

Disablement is represented by the verb to melt with the source and the target omitted in the slogan Melts in your mouth, not in your hands (M\&M's) (pinterest, e-ref). The source is not mentioned, but from the picture we can find out that it's the advertised product itself. The vector is represented by the predicate melts in the Present Simple Tense.

To conclude, disablement in headlines is most frequently expressed by the verbs to kill, to lose, to reject and in slogans - by means of verbs to kill, to melt. Unlike the Internet news headlines slogans contain pictures which convince people to buy advertised produce. The source and the result in slogans can be presented with the help of the picture. The next similar feature for slogans and most news headlines is the Present Simple Tense of verbs which shows that this piece of information is modern and fresh. Only one headline includes the verb in the Past Simple Tense to emphasize the result - losing life.

Conclusions. Headlines of news texts as riveting short-cuts to the contents of the articles perform two main functions: summarize the content and attract attention to the full-text article. the latter function is referred to as advertising.

The analysis of $30 B B C$ news stories and 20 advertising slogans from the websites Pinterest and Trademarks 411 demonstrates that news headlines are based on the same perceptual abilities as advertising slogans captured by image-schemas - recurring dynamic patterns of human perceptual interaction and motor programs structuring our experiences. The analysis has demonstrated that most frequently news headlines and slogans rely on force image schemas such as counterforce, compulsion, blockage, restraint removal, enablement and disablement. These image-schemas are elaborated by various causative verbs in the patterns consisting of three elements: the source, the vector and the target of force exertion in different combinations.

The prospects for future investigation are seen in the possibility of analyzing advertising function of headlines and titles in other types of media discourse.

\section{References:}

1. Althaus S.L. Using substitutes for full-text news stories in content analysis: which text is best? Scott L. Althaus, Jill A. Edy, Patricia F. Phalen. American Journal of Political Science. 2001. № 45. P. 707-723.

2. Andrew B.C. Media-generated Shortcuts: Do Newspaper Headlines Present Another Roadblock for Low-information Rationality? The Harvard International Journal of Press / Politics. 2007. Vol. 12. P. 24-43.

3. Bell A. The Language of News Media / Allan Bell. Oxford : Blackwell, 1991. 358 p.

4. Bowles D.A. Creative Editing / Dorothy A. Bowles, Diane Borden. Wadsworth, Belmont, CA, 2000. 423 p.

5. Gupta V.S. Handbook Of Reporting And Communication Skills / V.S. Gupta. New Delhi: Concept Publishing Company, 2003. 220 p.

6. Danylchenko I. Causal relations in English news magazine discourse: Journalists' age perspective. Discourse and Interaction. 2019. Vol. 12, № 2. In print.

7. Dubovičienė T., Skorupa P. The Analysis of some Stylistic Features of English Advertising Slogans. Man and the Word / Foreign Languages. 2014. Vol. 16, № 3 P. 61-75.

8. Hampe B. From Perception to Meaning: Image Schemas in Cognitive Linguistics. Berlin : Mouton de Gruyter, 2005. 467 p.

9. Ifantidou E. Newspaper headlines and relevance: Ad hoc concepts in ad hoc contexts. Journal of Pragmatics. 2009. № 41. P. 699-720.

10. Johnson M. The Body in the Mind: The Bodily Basis of Meaning, Imagination, and Reason. Chicago; L. : The Univ. of Chicago Press, 1987. 398 p.

11. Leon J.A. The effects of headlines and summaries on news comprehension and recall. Reading and Writing: An Interdisciplinary Journal. 1997. № 9. P. 85-106.

12. Potapenko S. Cognitive rhetoric of effect: energy flow as a means of persuasion in inaugurals. Topics in Linguistics. 2016. № 17, Vol. 2. P. 12-25.

13. Roberts J. Writing for Strategic Communication Industries. Columbus : The Ohio State University, 2016. 117 p.

14. Saxena S. Headline Writing. New Delhi : Sage Publications Inc., 2006. 342 p.

15. Smith Ed. J. Leadlines may be better than traditional headlines. Newspaper Research Journal. 1999. N 20. P. 55-64.

16. Thornburg R. Producing Online News: digital skills, stronger stories. Washington, D.C. : CQ Press, 2011. 360 p. 
Данильченко І., Зотікова Ю. Рекламна функція заголовків англомовних текстів новин: лінгвокогнітивний аспект

Анотація. Статтю присвячено аналізу мовних засобів створення заголовків англомовних новинних текстів. Розглядаючи заголовок як стислий зміст статті, його рекламна функція полягає у приверненні уваги до тексту. Встановлено, що на когнітивному рівні заголовки новин базуються на тих же механізмах, що й рекламні гасла. Різноманітні перцептивні відношення передаються образсхемами - повторюваними динамічними патернами нашої перцепції та рухових механізмів, що структурують досвід. Це дослідження засвідчує, що найчастіше заголовки новин та рекламні гасла спираються на силові образсхеми. Відношення ПРОТИДІї, сформовані під впливом досвіду зіткнення двох центрів сили, внаслідок чого жодна 3 них не може рухатися далі, представлені різними дієсловами у заголовках і рекламних гаслах. Заголовкам новин властиві дієслова to attack, to hit, to warn, у гаслах домінує дієслово to hit. ПРИМУШЕННЯ, за якого джерело здійснює вплив на ціль, лежить в основі значень дієслів to force, to make, to provoke у заголовках новин та to make i to obey у гаслах. ПЕРЕШКОДА, утворена силовим вектором, що зупиняється або змінює траєкторію внаслідок зіткнення 3 перепоною, позначена в заголовках дієсловами to reject, to jail, to sue, to trap, to poison і в гаслах за допомогою to cool i to jail. УСУНЕННЯ ПЕРЕШКОДИ, за якого Антагоніст, що блокував схильність Агоніста до руху, припиняє свою дію, позначену в заголовках дієсловами to answer, to find, to free, а в гаслах - to let i to answer. Образсхема ЗАБЕЗПЕЧЕННЯ МОЖЛИВОСТІ, імпЛікуючи вектор досягнення певної мети, лежить в основі значень дієслів to create, to give, to help, to make, to vote, властивих заголовкам новин, та дієслів to give, to help, що зустрічаються в гаслах. ПОЗБАВЛЕННЯ МОЖЛИВОСТІ представлене дієсловами to kill, to lose, to reject у заголовках й to kill, to melt у рекламних гаслах. Названі образ-схеми співвідносять референти $з$ джерелом, ціллю або вектором дії, підпорядкованим досягненню певної мети чи наміру.

Ключові слова: рекламна функція, заголовок, гасло, дискурс новин, мовні засоби, образ-схема. 